\title{
Rare case of adult pancreatoblastoma
}

\author{
George Morrissey, Patrizia Cohen, Maximilian Julve
}

Oncology, Imperial College

London, London, UK

Correspondence to

Dr Maximilian Julve;

maximilian.julve@nhs.net

Accepted 15 March 2020

Check for updates

(C) BMJ Publishing Group Limited 2020. No commercial re-use. See rights and permissions. Published by BMJ.

To cite: Morrissey $\mathrm{G}$ Cohen P, Julve M. BMJ Case Rep 2020;13:e233884 doi:10.1136/bcr-2019233884

\section{DESCRIPTION}

A 69-year-old man with a background of hypertension, benign prostatic hypertrophy and Eastern Cooperative Oncology Group (ECOG) performance status 0 , presented with abdominal pain and weight loss in May 2018. Biochemistry and full blood count were unremarkable, notably with normal liver function and tumour markers. CT revealed a $5.5 \times 4.5 \mathrm{~cm}$ mass in the head of the pancreas, in contact with the superior mesenteric artery and portal vein, with superior mesenteric vein (SMV) thrombus. Endoscopic ultrasound (EUS)-guided core biopsy was reported as acinar cell carcinoma, with immunohistochemistry positive for $\mathrm{CD} 8 / \mathrm{CD} 18, \alpha$-1-antitrypsin and $\alpha-1$ antichymotrpysin. Due to the locally advanced nature of the mass it was deemed inoperable and he went on to receive eight cycles of neoadjuvant FOLFIRINOX. Repeat CT displayed an excellent partial response and subsequently proceeded to an open Whipple's procedure with resection and reconstruction of the SMV. Postoperative histopathology unexpectedly displayed pancreatoblastoma (figure 1), measuring $3.4 \times 3.7 \mathrm{~cm}$, with staging pT2 N0 M0. The specimen was deemed R1 resection due to viable tumour extending to the anterior pancreatic surface. At 10 weeks post operatively, restaging revealed no measurable disease and he was treated with six cycles of adjuvant gemcitabine and capecitabine chemotherapy.

Pancreatoblastoma is a rare malignant neoplasm of the pancreas with a bimodal pattern of presentation. There have been approximately 40 documented cases in adults since first reported in 1957 , and over 200 in children. ${ }^{1}$ The tumour more commonly occurs at the head of the pancreas (49\% of cases) and the most common presenting complaint is abdominal pain. ${ }^{2}$ It can present a diagnostic challenge as tumour markers are often non-contributary and abdominal imaging may be consistent with both benign and malignant neoplasms as well as autoimmune pancreatitis. The diagnosis is based on histological demonstration of heterogeneous cellularity with acinar differentiation and characteristic squamoid nests (figure 1). ${ }^{3}$ EUS biopsy may fail to capture these specific structural characteristics leading to misdiagnosis. The aetiology is unknown but it has been associated rare genetic syndromes such as BeckwithWiedeman and familial adenomatous polyposis. ${ }^{13}$ It is named pancreatoblastoma due to its histological resemblance to fetal pancreatic tissue, and in contrast to pancreatic adenocarcinomas it rarely seems to exhibit p53 and KRAS alterations. ${ }^{1}$ Previous documented cases have suggested that it behaves aggressively, commonly invading adjacent strictures including the duodenum, spleen, superior

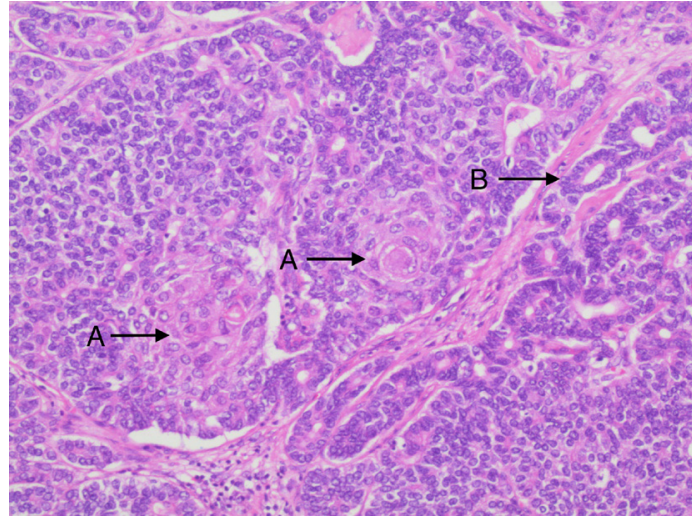

Figure 1 Pancreatoblastoma showing two characteristic squamoid nests (A) surrounded by sheets of smaller cells showing focal acinar arrangements (B). The nests are composed of whorled plump squamoid cells with eosinophilic cytoplasm which is more abundant than that of the surrounding acinar cells. The acinar component shows cellular sheets of uniform polygonal cells with regular central nuclei and cells in acinar arrangements with the neoplastic cells polarised around small lumens. H\&E $\times 100$ magnification.

mesenteric vessels, common bile duct and peripancreatic soft tissue. ${ }^{2}$ Metastasis and/or invasion of adjacent structures has been documented in $58 \%$ of cases with the liver being the most common site. ${ }^{2}$

Pancreatoblastoma is an extremely rare form of pancreatic cancer and there are no established guidelines for management of this aggressive disease. Surgical resection is advised if anatomically possible, and the role of chemoradiotherapy is unclear. It has worse outcomes in adults than in children, but with limited evidence it is difficult to offer accurate prognostics. This case demonstrates the diagnostic challenges and potential role of perioperative chemotherapy in this rare cancer. The disease should be included in the differential diagnosis of pancreatic neoplasms and may only be

\section{Learning points}

Adult pancreatoblastoma is a rare subtype of pancreatic cancer that can be difficult to diagnose on endoscopic ultrasound biopsy alone.

- Diagnosis relies on histopathological confirmation of characteristic squamoid nests, as acinar differentiation alone is indistinguishable from acinar cell carcinoma.

- Malignancies of the pancreatic head can present without the typically described painless jaundice and deranged liver function tests. 
diagnosed after thorough histopathological analysis of resected specimens.

Twitter George Morrissey @GjMorrissey and Maximilian Julve @JulveMax

Contributors GM wrote first draft. PC provided pathological image and description. MJ coordinated project, consented patient, edited text and image.

Funding The authors have not declared a specific grant for this research from any funding agency in the public, commercial or not-for-profit sectors.

Competing interests None declared.
Patient consent for publication Obtained.

Provenance and peer review Not commissioned; externally peer reviewed.

\section{REFERENCES}

1 Zouros E, Manatakis DK, Delis SG, et al. Adult pancreatoblastoma: a case report and review of the literature. Oncol Lett 2015;9:2293-8.

2 Omiyale AO. Clinicopathological review of pancreatoblastoma in adults. Gland Surg 2015;4:322-8.

3 Hammer STG, Owens SR. Pancreatoblastoma: a rare, adult pancreatic tumor with many faces. Arch Pathol Lab Med 2013;137:1224-6.

Copyright 2020 BMJ Publishing Group. All rights reserved. For permission to reuse any of this content visit

https://www.bmj.com/company/products-services/rights-and-licensing/permissions/

BMJ Case Report Fellows may re-use this article for personal use and teaching without any further permission.

Become a Fellow of BMJ Case Reports today and you can:

- Submit as many cases as you like

- Enjoy fast sympathetic peer review and rapid publication of accepted articles

- Access all the published articles

Re-use any of the published material for personal use and teaching without further permission

\section{Customer Service}

If you have any further queries about your subscription, please contact our customer services team on +44 (0) 2071111105 or via email at support@bmj.com.

Visit casereports.bmj.com for more articles like this and to become a Fellow 